\title{
カルシウムおよびマグネシウム塩の水溶液からの加熱缶壁に おけるアルカリスケールの析出機構
}

(1972 年 4 月 18 日受理)

\author{
後藤 忠俊・白崎 高 保*
}

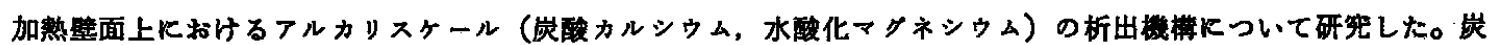

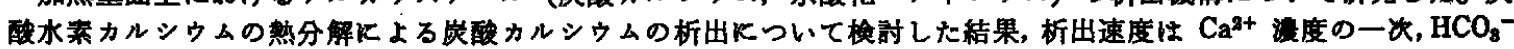
浱度の二次に此例するこ之，見かけの活性化エネルギーが $25 \mathrm{kcal} / \mathrm{mol}$ であること，主た溶存二酸化炭莱は反応過程 中注一定であることを明らか炕した。これらの結果から炭酸カルシウムの析出反応では結晶析出過程が律速である と考察した。

マグネシゥム塩水溶液中での炭酸カルシゥムの高温加水分解基つく水酸化マグネシウムの析出について検討し，

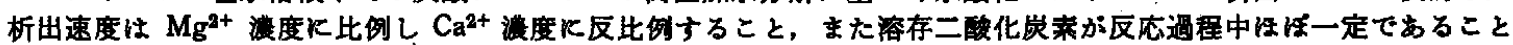
がわかった。これらの結果から水酸化マグネシウムの析出反応においてす結晶析出過程が律速段階であろらと考寮し た。

沸点付近での海水からのフルカリスケールの析出実鍳の結果，ます海水中の炭酸水来イオンが分解して炭酸かルシ ウムが析出し，ついで炭酸カルシウムの分解消失にともなって水酸化マグネシウムが逐次的に析出することを明らか

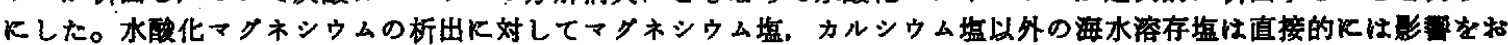
よぼさないようである。
\end{abstract}

\section{1 楮 宦}

海水の加熱灌縮工程で卮熱管壁面上飞析出する硫酸カルシウム スケール $\left(\mathrm{CaSO}_{4} \cdot n \mathrm{H}_{2} \mathrm{O} ; n=0,1 / 2,2\right)$, アルカリスケール (Ca・ $\left.\mathrm{CO}_{3}, \mathrm{Mg}(\mathrm{OH})_{2}\right)$ は熱效率を下げ操作上の障害となる。硫酸カル シウムスケールはその溶液の濩縮によって析出するが, 峞酸カル シウムスケールは炭酸水素カルシウムの熱分解により，また水酸 化マグネシウムスケールは炭酸イオンの高温加水分解で生ずる水 酸イオンと海水溶存マグネシウム塩との反応により后熱管壁面上 に析出するといわれている。著者の一人は硫酸カルシウム 2 水塩 のスケール析出機構(1) - 3)，アルカリスケール析出現象と 3 種海塩 スケール物質の相互関係についですでに研究したが，ここでは アルカリスケールの析出機構について検討した結果を報告する。

\section{2 実㖔}

実験に使用した装圈は既報》と同様のすのでニクロム線ヒーメ 一を内包する銅製内管（外径 $1.0 \mathrm{~cm}$, 長さ $10 \mathrm{~cm}$ ) とガラス製 外管（内径 $4.0 \mathrm{~cm}$, 長さ $30 \mathrm{~cm}$ ) との二重管から成る 熱交換部 を主体とした循環系装登である。炭酸カルシウムスケールは所定 濃度の炭酸水素カルシウム溶液（塩化カルシウムと炭酸水秦ナト

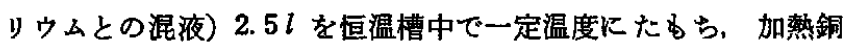
管の外側に $1.2 \mathrm{l} / \mathrm{min}$ の流速で循瑀させ，加熱壁面上に析出させ た。実験は炭酸カルシウムが加熱壁面上にのみ析出し，母液中で は晶出しないような溶液濃度の範囲で行なった。以下で反応温度 は壁面温度をもって示した。壁面温度はエナメルシールした熱電

* 東京工業大学资源化学研究所, 東京都目黒区大网山

1）後藤忠俊, 室谷 宽, 工化, 70, 2235(1967).

2) 後藤忠俊, 室谷 寛, 工化, 71, 1833(1968).

3）室谷 寛, 後藤忠俊, 石高と石灰、99，5(1969).

4) 室谷 寛, 後藤忠俊, 他, 海水詿, 24, 183(1971).
対の先端を壁面に密着して测定した。銅管の上下部で約 $3^{\circ} \mathrm{C} の$ 差があったが，壁面㴜度の表示はその平均値をとった。熱交換部 入口での溶液が $40,50, " 60^{\circ} \mathrm{C}$ の各温度のとき（熱交換部出口で の溶液温度は約 $1.5^{\circ} \mathrm{C}$ 高い)，暨面温度はそれぞれ $64,72,80^{\circ} \mathrm{C}$ であった。反庶過程の溶液組成の变化量を測定し、これから炭酸 カルシウムの析出速度を求めた。溶液成分の $\mathrm{Ca}^{2+}$ はキレート滴 定法で, $\mathrm{HCO}_{8}{ }^{-}, \mathrm{CO}_{3}{ }^{2-}$ は酸滴定法で分析し，固体析出物の組成 はX線分析法によって調べた。

水酸化マグネシウムスケールの析出実験す上記と同し装置を用 いて行なった。まず，上記の方法により，初浱度 $\mathrm{CaCl}_{2} 10 \mathrm{mmol} / l$, $\mathrm{NaHCO}_{3} 5 \mathrm{mmol} / \mathrm{l}$ の溶液を用いて区応温度 $64^{\circ} \mathrm{C}$, 反応時間 3 時 間で炭酸カルシウム約 $0.7 \mathrm{~g}$ を付着した加熱銅管を準備した。こ のまわりに $98^{\circ} \mathrm{C}$ の一定温度にたもった硫酸マグネシウム溶液 $2.5 l$ を循裳させ（壁面渴度 $100^{\circ} \mathrm{C}$ ), 加熱壁面上飞水酸化マグネ シウムを析出させた。所定の反応時間ごとに壁面析出物の組成変 化を粉末 X線分析法，化学分析により湘定し，水酸化マグネシウ 么の析出速度を求めた。

\section{3 結果}

\section{1 炭酸カルシウムの析出}

3.1 .1 析出速度の温度依存性：炭酸水素カルシウム溶液の加 熱分解による炭酸カルシウムスケールの析出速度におよぼす反応 温度の影響について謂べた。まず，壁面温度 $64^{\circ} \mathrm{C}$, 溶液初蕞度 $\mathrm{CaCl}_{2} 24.2 \mathrm{mmol} / l, \mathrm{NaHCO}_{8} 4.70 \mathrm{mmol} / \mathrm{l}$ で反応を行なった。 このときの $\mathrm{Ca}^{2+}$ 濃度および $\mathrm{HCO}_{3}$ - 濃度の経時変化は図 1 K示 すと拈りである。反応初期には $\mathrm{Ca}^{2+}$ 濃度および $\mathrm{HCO}_{3}{ }^{-}$浱度は 反応時間に対しほぼ直線的に減少し、 $\mathrm{Ca}^{2+}$ 濃度の減少速度は $\mathrm{HCO}_{3}{ }^{-}$濃度の减少速度の $1 / 2$ である。このことはつぎの(1) 式 の反応が化学量論的に進行することを示しており，炭酸カルシウ ムの析出速度を溶液中の $\mathrm{Ca}^{2+}$ 灌度の減少速度で表わすことがで 


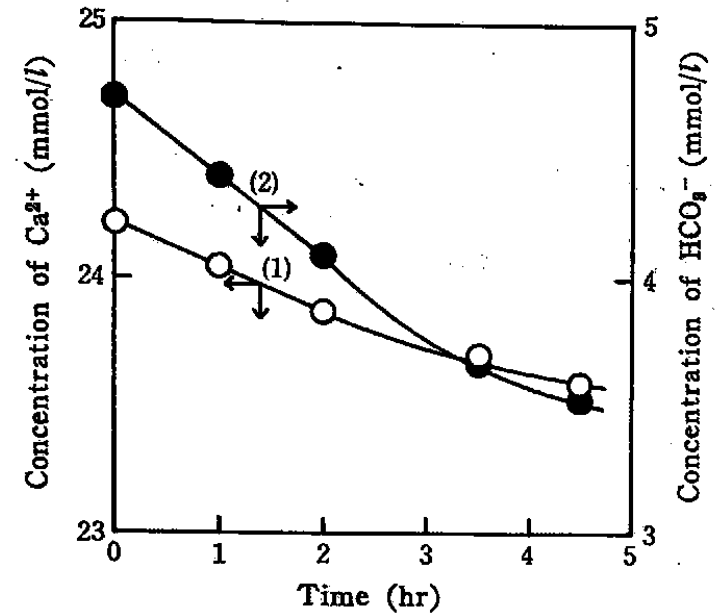

Fig. 1 Concentration of $\mathrm{Ca}^{3+}$ and $\mathrm{HCO}_{3}-$ in the process of $\mathrm{CaCO}_{9}$ deposition on heated surface $\left(64^{\circ} \mathrm{C}\right)$

(1) : $\left[\mathrm{Ca}^{2+}\right],(2):\left[\mathrm{HCO}_{3}{ }^{-}\right]$

きる。

$$
\mathrm{Ca}\left(\mathrm{HCO}_{3}\right)_{2} \longrightarrow \mathrm{CaCO}_{3}+\mathrm{CO}_{2}+\mathrm{H}_{2} \mathrm{O}
$$

析出物㤋末 $\mathrm{X}$ 線分析の結果, 炭酸カルシウム（アラゴナイト） であった。図 1 から炭酸カルシウム析出の初速度は $0.15 \mathrm{mmol}$ ・ $l^{-1} \cdot h r^{-1}$ である。

同様にして塩化カルシウム，炭酸水絜ナトリウムの初湄度をい ろいろ変え, 壁面温度 $64,72,80^{\circ} \mathrm{C}$ のとき炭酸カルシゥム析 出速度を求めた。結果を表 1 K示す。既報》で推定された下記の （2）の速度表式にしたがって速度定数 $k_{1}$ を求めたところ，64 ${ }^{\circ} \mathrm{C}$ では平均 $3.0 \times 10^{-4}\left(\mathrm{mmol}^{-2} \cdot l^{-1} \cdot \mathrm{hr}^{-1}\right), 72^{\circ} \mathrm{C}$ では $7.7 \times 10^{-4}$, $80^{\circ} \mathrm{C}$ では $1.2 \times 10^{-8}$ であった。すなわち $k_{1}$ は初濃度化かかわ りなく各温度ごとKほぼ一定値となった。このことから疢酸カル シウム析出反応は $\mathrm{Ca}^{+2}$ 港度に一次, $\mathrm{HCO}_{3}$ 漂度に二次であるこ

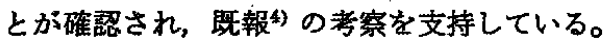

$$
r_{1}=k_{1}\left[\mathrm{Ca}^{2+}\right]\left[\mathrm{HCO}_{3}^{-}\right]^{2}
$$

ここで $r_{1}$ は炭酸カルシウム析出速度, $k_{1}$ はその速度定数, $\left[\mathrm{Ca}^{2+}\right]$ は $\mathrm{Ca}^{2+}$ 濃度, $\left[\mathrm{HCO}_{8}^{-}\right]$ほ $\mathrm{HCO}_{3}^{-}$涨度である。

Arrhenius プロットをとると図2のようになり，これから求め

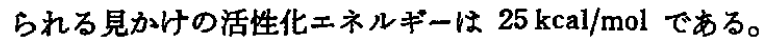

Table 1 Deposition of calcium carbonate at various

\begin{tabular}{|c|c|c|c|c|}
\hline \multirow{2}{*}{$\begin{array}{c}\text { Surface } \\
\text { temp. } \\
\left({ }^{\circ} \mathrm{C}\right)\end{array}$} & \multicolumn{2}{|c|}{$\begin{array}{l}\text { Initial conc. } \\
(\mathrm{mmol} / l)\end{array}$} & \multirow{2}{*}{ 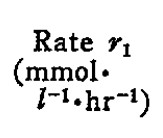 } & \multirow{2}{*}{$\begin{array}{c}\text { Rate const. } \\
\left.k_{1} a\right) \\
\left(\mathrm{mmol}^{-2} .\right. \\
\left.l^{-1} \cdot \mathrm{hr}^{-1}\right)\end{array}$} \\
\hline & $\mathrm{CaCl}_{2}$ & $\mathrm{NaHCO}_{3}$ & & \\
\hline \multirow{3}{*}{64} & 24.2 & 4.70 & 0.15 & $2.8 \times 10^{-4}$ \\
\hline & 14.4 & 4. 75 & 0.10 & $3.1 \times 10^{-4}$ \\
\hline & 14.6 & 2. 39 & 0.025 & 3. $0 \times 10^{-4}$ \\
\hline \multirow{3}{*}{72} & 14.1 & 2.70 & 0.080 & $7.8 \times 10^{-4}$ \\
\hline & 14.5 & 2. 23 & 0.056 & $7.7 \times 10^{-4}$ \\
\hline & 7.5 & 2.65 & 0.040 & $7.6 \times 10^{-4}$ \\
\hline \multirow{3}{*}{80} & 14.0 & 2. 32 & 0.090 & $1.2 \times 10^{-3}$ \\
\hline & 14.6 & 1.51 & 0.035 & $1.1 \times 10^{-3}$ \\
\hline & 9.0 & 2. 20 & 0.054 & 1. $2 \times 10^{-8}$ \\
\hline
\end{tabular}
surface temperature

a) Determined value from the equation: $r_{1}=k_{1}\left[\mathrm{Ca}^{2+}\right]$. $\left[\mathrm{HCO}_{3}^{-}\right]^{2}$.

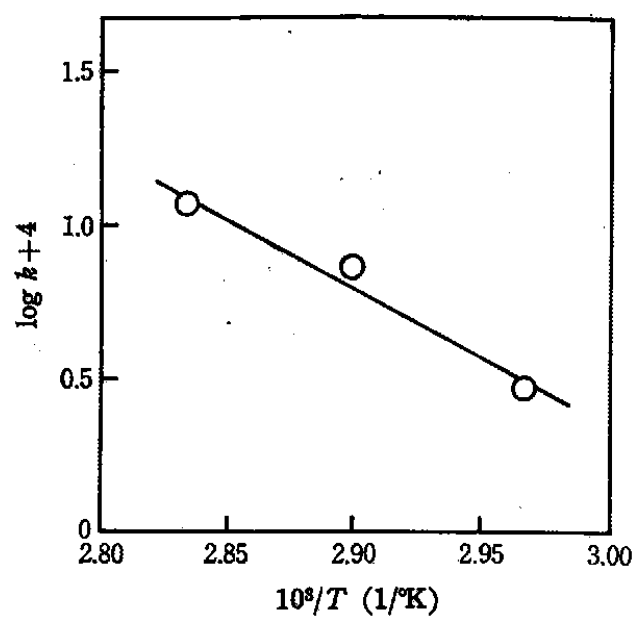

Fig. 2 Arrhenius plots of the deposition of $\mathrm{CaCO}_{3}$ on heated surface

3.1 .2 生成二酸化炭素の挙動：(1) 式による炭酸カルシウム の析出反応では二酸化炭素が生成する。この生成二酸化炭紊の举 動は炭酸カルシウム析出速度に影䉕すると考えられるので，反応 過程での溶液中の溶存二酸化炭热濃度について調べた。

水溶液中で $\mathrm{CO}_{2}, \mathrm{HCO}_{8}+, \mathrm{CO}_{3}^{2+}, \mathrm{H}^{+}$の間につぎの平衡が知ら れている。

$$
\begin{aligned}
& \mathrm{CO}_{2}+\mathrm{H}_{2} \mathrm{O} \rightleftarrows \mathrm{HCO}_{3}^{-}+\mathrm{H}^{+} \\
& \mathrm{HCO}_{3}^{-} \rightleftarrows \mathrm{CO}_{3}^{2-}+\mathrm{H}^{+}
\end{aligned}
$$

（3），(4）式に拈ける平衡定数をそれぞれ $K_{1} ， K_{2}$ とすると近 似的飞

$$
\begin{aligned}
& K_{1}=a_{\mathrm{H}^{+}} \cdot c_{\mathrm{HCO}_{3}-} / c_{\mathrm{CO}_{2}} \\
& K_{2}=a_{\mathrm{H}^{+}} \cdot c_{\mathrm{CO}_{32}-} / c_{\mathrm{HCO}_{3}-}
\end{aligned}
$$

ここで $a$ は活動度， $c$ は濃度である。 $K_{1}, K_{2}$ は詳しく知られて いるので, $a_{\mathrm{H}^{+}}, c_{\mathrm{HCO}_{3}-}, c_{\mathrm{CO}_{32-}}$ を知れば（5)，(6) 式から溶存 二酸化炭素濃度 $c_{\mathrm{CO}_{2}}$ は求められる。

反応温度 $64^{\circ} \mathrm{C}$, 初濃度 $\mathrm{CaCl}_{2} 14.40 \mathrm{mmol} / l, \mathrm{NaHCO}_{3} 4.80$ $\mathrm{mmol} / l$ の場合の反応過程に拈ける溶存二酸化炭素謴度は表 2 の ようになる。 $\mathrm{pH} 7.82$ 以下のこの溶液に批いては $c_{\mathrm{CO}_{3}{ }^{2}}$ は無視 できるぼはさく， $c_{\mathrm{HCO}_{3}}$ と $\mathrm{pH}$ 值とから(5)式を用いて $c_{\mathrm{CO}}$ が求められる。Harvey方 に上れば $64^{\circ} \mathrm{C}$ で $K_{1} \fallingdotseq 6.0 \times 10^{-7}$ であ る。大般と平衡にる反応液中に初期から溶存している二酸化炭 紊濃度は $0.12 \mathrm{mmol} / l$ であり， $\mathrm{HCO}_{3}-$ の分解に上る生成二酸化 炭素がすべて反応液に溶解しているとすれば反応時間ととるにそ の濃度は増加し，反応 300 分で $0.57 \mathrm{mmol} / l$ となるはずである (表 2 第 6 列)。しかし実測された $c_{\mathrm{HCO}_{3}-}, \mathrm{pH}$ 値から求められた 溶存二酸化炭素濃度は反応 75 分以降では $0.21 \mathrm{mmol} / l$ でほぼー 定となった(表 2 第 5 列)。したがって開放循環系装置を用いた本 実験の場合には約 1 時間後には生成二酸化炭素と系外に放出され る二酸化炭素とが等しくなっているものと考えられる。初濃度の 異なる他の实験の場合です反応過程中の溶存二酸化炭素濃度は $0.21 \mathrm{mmol} / l$ ではばー定であった。

5) H. W. Harvey, "The Chemistry and Fertility of Sea Water", Interscience Pub, Inc., New York (1957) p. 153. 
Table 2 Concentration of dissolved $\mathrm{CO}_{2}$ through the process of the reaction $\left(64^{\circ} \mathrm{C}\right)$

\begin{tabular}{rccccc}
$\begin{array}{c}\text { Time } \\
(\mathrm{min})\end{array}$ & $\begin{array}{c}\mathrm{Ca}^{2+} \\
(\mathrm{mmol} / l)\end{array}$ & $\begin{array}{c}\mathrm{HCO}_{8}^{-} \\
(\mathrm{mmol} / l)\end{array}$ & $\mathrm{pH}$ & $\begin{array}{c}\left.\mathrm{CO}_{2}{ }^{a}\right) \\
(\mathrm{mmol} / l)\end{array}$ & $\begin{array}{c}\left.\mathrm{CO}_{2}{ }^{b}\right) \\
(\mathrm{mmol} / l)\end{array}$ \\
\hline 0 & 14.40 & 4.80 & 7.82 & 0.12 & 0.12 \\
75 & 14.31 & 4.48 & 7.60 & 0.21 & 0.20 \\
120 & 14.22 & 4.32 & 7.53 & 0.21 & 0.30 \\
180 & 14.13 & 4.09 & 7.52 & 0.21 & 0.38 \\
240 & 14.04 & 3.86 & 7.45 & 0.23 & 0.48 \\
300 & 13.95 & 3.69 & 7.46 & 0.21 & 0.57
\end{tabular}

a) Determined value of dissolved $\mathrm{CO}_{2}$.

b) Calculated value of produced $\mathrm{CO}_{2}$ from the reaction.

\section{2 水酸化マグネシウムの析出}

約 $0.7 \mathrm{~g}$ の炭酸カルシウムをあらかじめ付着させた加熱銅管の まわりに $98^{\circ} \mathrm{C} の 一$ 定温度にたるった $50 \mathrm{mmol} / \mathrm{l}$ の硫酸マグネシ ウム溶液 $2.5 l$ を循瓄した（篮面温度 $100^{\circ} \mathrm{C}$ )。このときの反応 時間と壁面析出物の組成との関係は図 3 のよらになった。析出物 は粉末 X線分析の結果いずれる岩酸カルシウム（アラゴナイト） と水酸化マグネシウムとの混合物であった。付着炭酸カルシウム の一部が硫酸マグネシウム溶液に溶解するため, 反応 10 分後の 付着物は約 $0.3 \mathrm{~g}$ になっていた。水酸化マグネシウムの析出量は 反応初期は時間に対してほぼ直線的に增加し，図 $3(2)$ 加ら求め られる析出速度は $15 \mathrm{mg} / \mathrm{hr}$ である。

本実験ては反応開始前の付着炭酸カルシウム量を正確化一定と することが困難であり，また壁面沸睠なとのため反応時間が長く なると壁面付着物の一部が䟝離する場合があるので, 以下では水 酸化マグネシウムの析出速度を次式に示す無次元化された補正析 出量を用いて表わした。補正析出速度は灰酸カルシウムが消耗す るとそのすべてが反応して当量の水酸化マグネシウムが付着析出 するとして計算された析出速度に相当する。

\section{$\mathrm{Mg}(\mathrm{OH})_{2}$ の補正析出量 $=M_{\mathrm{Mg}(\mathrm{OH})_{2}} /\left(\mathrm{M}_{\mathrm{CaCO}_{3}}+M_{\mathrm{Mg}(\mathrm{OH})_{2}}\right)$}

ここで $M_{\mathrm{Mg}(\mathrm{OH})_{2}}$ は $\mathrm{Mg}(\mathrm{OH})_{2}$ の析出モル数, $M_{\mathrm{CaCO}_{3}}$ は $\mathrm{CaCO}_{3}$ の析出モル数である。図 3 ( 3 )から求められる反応初期の補正析

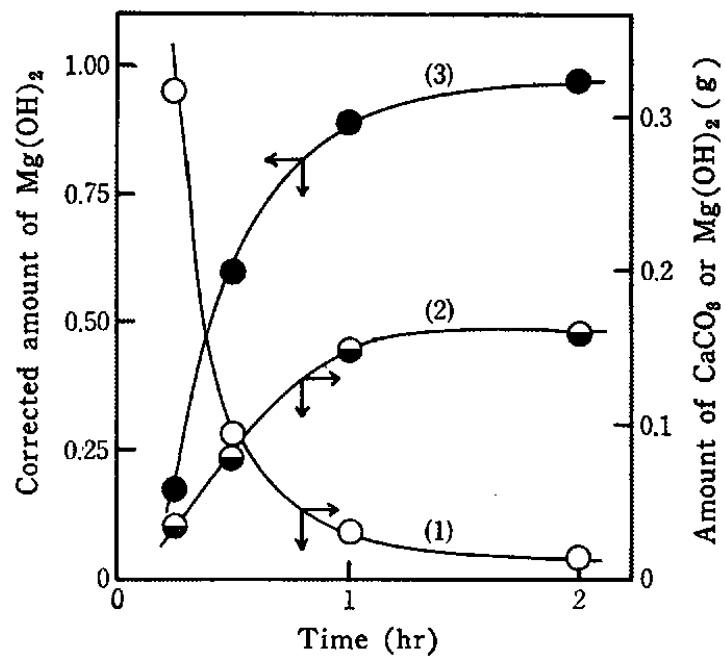

Fig. 3 Deposition of $\mathrm{Mg}(\mathrm{OH})_{2}$ scale on heated surface by hydro-decomposing of $\mathrm{CaCO}_{3}$ in solution $\left(\mathrm{MgSO}_{4}\right.$ $50 \mathrm{mmol} / l$ )

(1) $: \mathrm{CaCO}_{3}, \quad$ (2): $\mathrm{Mg}(\mathrm{OH})_{2}$, (3) : Corrected amount of $\mathrm{Mg}(\mathrm{OH})_{2}$
出速度は約 $1.0(1 / \mathrm{hr})$ でする。

同様にして，反応溶液の組成を変えたときの水酸化マク゚ネシウ ムの壁面析出速度を求めた。（1） $\mathrm{MgSO}_{4} 25 \mathrm{mmol} / l$, (2) $\mathrm{Mg}$ ・ $\mathrm{SO}_{4} 10 \mathrm{mmo} / \mathrm{l}$, (3) $\left(\mathrm{MgSO}_{4} 50 \mathrm{mmol}+\mathrm{CaCl}_{2} 5 \mathrm{mmol}\right) / l$, (4) $\left(\mathrm{MgSO}_{4} 50 \mathrm{mmol}+\mathrm{CaCl}_{2} 10 \mathrm{mmol}\right) / l$, の 4 種溶液を用いた場合 の反応時間と水酸化マグネシウムの補正析出昷の関係は图 4 のと おりである。

図3および图 4(1)，(2) から求めた補正析出速度と $\mathrm{Mg}^{2+}$ 港 度との関係は図 5(1)のよ5な直線となる。また炭酸カルシウム の溶解度を考虑して，図 3 および図 4 (3)，(4) から求めた補正 析出速度と $\mathrm{Ca}^{2+}$ 濃度の逆数の関係をブロットすると図 5 (2)の よらにほぼ直線となる。この場合の $\mathrm{Mg}^{2+}$ 濃度は $50 \mathrm{mmol} / \mathrm{l} の$

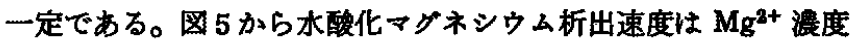

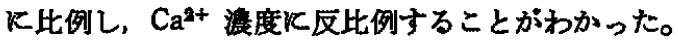

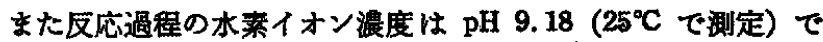

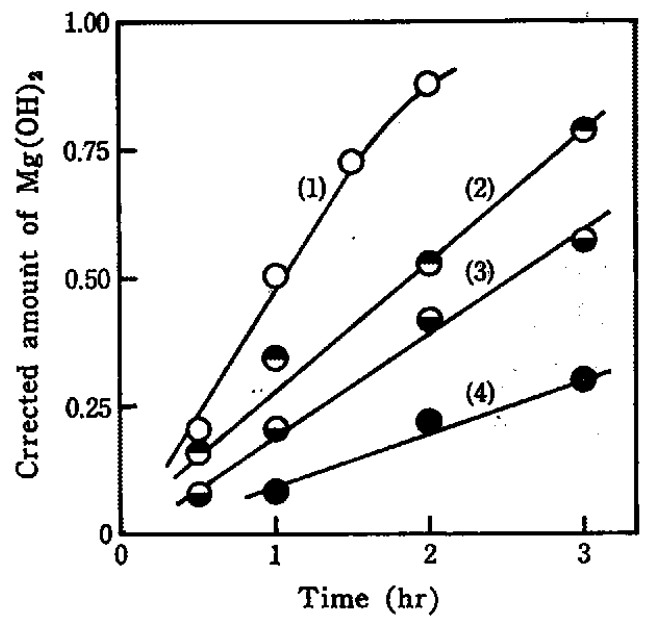

Fig. 4 Decomposition of $\mathrm{Mg}(\mathrm{OH})_{2}$ on heated surface by hydro-decomposition of $\mathrm{CaCO}_{8}$ in the solution

(1) : $\mathrm{MgSO}_{4} 25 \mathrm{mmol} / \mathrm{l}$, (2) $: \mathrm{MgSO}_{4} 10 \mathrm{mmol} / \mathrm{l}$, (3): $\left(\mathrm{MgSO}_{4} 50 \mathrm{mmol}+\mathrm{CaCl}_{2} 5 \mathrm{mmol}\right) / l,(4):\left(\mathrm{MgSO}_{4} 50 \mathrm{mmol}\right.$ $\left.+\mathrm{CaCl}_{2} 10 \mathrm{mmol}\right) / l$

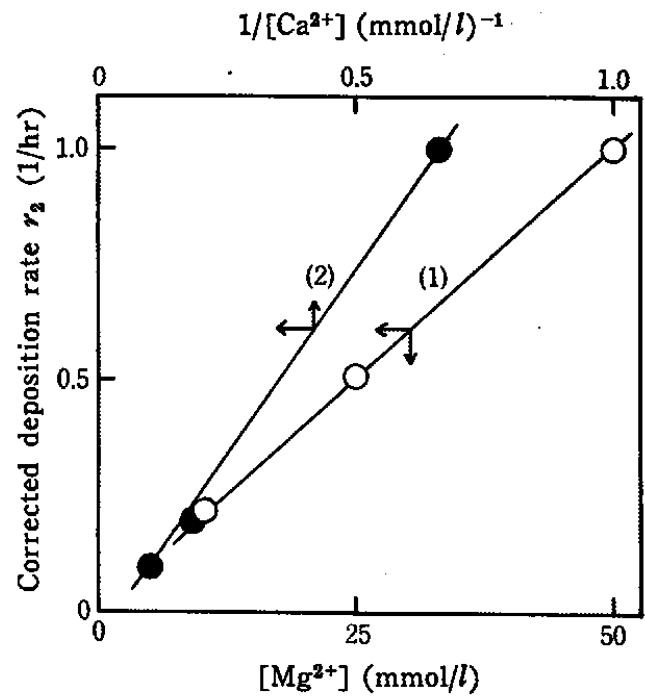

Fig. 5 Relation between the deposition rate of $\mathrm{Mg}(\mathrm{OH})_{2}$ scale and the concentration of $\mathrm{Mg}^{2+}$ or $\mathrm{Ca}^{2+}$

(1) $: r_{2}$ versus $\left[\mathrm{Mg}^{2+}\right],(2): r_{2}$ versus $1 /\left[\mathrm{Ca}^{2+}\right]$ 


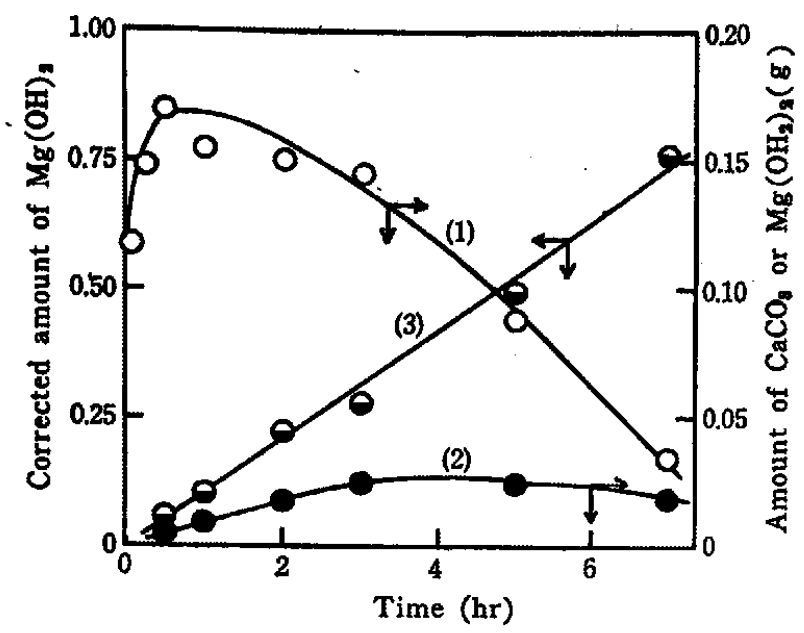

Fig. 6 Deposition of $\mathrm{Mg}(\mathrm{OH})_{2}$ scale on heated surface by hydro-decomposition of $\mathrm{CaCO}_{8}$ in the sea water

(1) : $\mathrm{CaCO}_{8}, \quad$ (2): $\mathrm{Mg}(\mathrm{OH})_{2}$, (3) : Corrected amount of $\mathrm{Mg}(\mathrm{OH})_{2}$

ほ悢一定值であり， $\mathrm{CCO}_{3}{ }^{2}$ すほぼ一定であうた。このことから $\mathrm{CO}_{8}^{2-}$ の分解化よって生成する二酸化质素は定常的俰系外に放出 され，反応過程の溶存二酸化孷素瀆度はほぼ一定であると考えら れる。

つぎK人工海水りを用いた場合の水酸化マグネシウム析出速度 を同様にして測定したところ図 6 に示才結果を得た。反结 15 分 後には人工海水中の $\mathrm{HCO}_{8}$ - はすべて分解し，その間成酸カルシ ウム付着旦増加し， $\mathrm{HCO}_{\mathrm{s}}-$ が分解し終ると付着孷酸カルシウ 内量は減少しはじめる。水酸化マグネシウム付着量は反応開始直 後から增加するが，反応時間が長くなると壁面沸膿なとのため㔀 雄して付着量は減少する。補正析出量で表わすと図6（3）のよう になり，時間に対して直線的に增加する。これから求められる水 酸化マグネシウムの補正析出速度は $0.11(1 / \mathrm{hr})$ で，マグネシウ ム、カルシウムのイオン湮度が人工海水と同程度の図 4 ( 3 )の場 合 $\left(\mathrm{MgSO}_{4} 50 \mathrm{mmol} / \mathrm{l}, \mathrm{CaCl}_{2} 10 \mathrm{mmol} / \mathrm{l}\right)$ の值 $0.10(1 / \mathrm{hr})$ と ほぼ同じ值となった。このことは海水中のマグネシウム塩, カル シウム塩以外の溶存塩は水酸化マグネシウム析出速度に直接的に は影繁を与えないことを示唆している。

\section{4 考察}

以上の笑絤結果からつぎのことが考えられる。

（1）疲酸水素カルシウム水溶液の加水分解による孷酸カルシ ウムの加熱壁面上に拈ける析出過程を検討した結果, 析出速度は $\mathrm{Ca}^{2+}$ 浱度飞一次， $\mathrm{HCO}_{\mathrm{s}}$ - 濃度に二次であること，見かけの活性 化エネルギーが $25 \mathrm{kcal} / \mathrm{mol}$ であること, 溶存二酸化炭素は反応 過程中ほぼ一定であることを実驗的に明らかにした。

一方，炭酸カルシウムスケールの析出過程はつぎの 4 段階より 成ると考えられる。すなわち，（1）溶質炭酸水素カルシウムの

6) 人工海水は Kalle の処方》によった。 その組成は $\mathrm{NaCl}$ $410 \mathrm{mmol} / l, \mathrm{MgCl}_{2} 53.3 \mathrm{mmol} / l, \mathrm{CaCl}_{2} 10.6 \mathrm{mmol} / l$, $\mathrm{KCl} 9.1 \mathrm{mmol} / l, \mathrm{KBr} 0.8 \mathrm{mmol} / l, \mathrm{Na}_{2} \mathrm{SO}_{4} 28.1 \mathrm{mmol} / l$, $\mathrm{NaHCO}_{8} 23.8 \mathrm{mmol} / \mathrm{l}$ である.

7）日本海水学会編，“海塩の化学”，塩業組合中央会（1966） p. 30 .

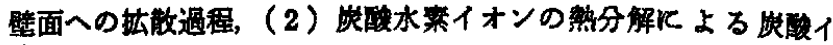
オンの生成過程，（3）岸酸カルシウムの結晶析出過程，（4）生 成二酸化能来の拡散脱離過程，の4段階である。ところが見かけ の活性化エネルキ゚ーの值からみてこの反応は払散律速とは考えら れない。上記（3）の過程が律速であると仮定すればこの析出反 応は次式で表わされる。

$$
\begin{aligned}
& 2 \mathrm{HCO}_{8}-\rightleftarrows \mathrm{CO}_{8}^{2-}+\mathrm{CO}_{2}+\mathrm{H}_{2} \mathrm{O} \\
& \mathrm{Ca}^{2+}+\mathrm{CO}_{3}^{2-} \longrightarrow \mathrm{CaCO}_{8} \text { (cryst.) }
\end{aligned}
$$

（7）式の平衡定数を $K_{8} ，(8)$ 式の速度定数を $k_{1}^{\prime}$ ，析出速度を $r_{1}$ とおけば,

$$
\begin{aligned}
& \left\{\begin{array}{l}
K_{3}=\left[\mathrm{CO}_{3}^{2-}\right]\left[\mathrm{CO}_{2}\right] /\left[\mathrm{HCO}_{3}{ }^{-}\right] \\
r_{1}=k_{1}{ }^{\prime}\left[\mathrm{Ca}^{2+}\right]\left[\mathrm{CO}_{3}^{2-}\right]
\end{array}\right. \\
\therefore \quad & r_{1}=k_{1}\left[\mathrm{Ca}^{2+}\right]\left[\mathrm{HCO}_{8}\right]^{2}
\end{aligned}
$$

ここで

$$
k_{1}=K_{8} k_{1} /\left[\mathrm{CO}_{2}\right]=\text { 一定 }\left(\because\left[\mathrm{CO}_{2}\right]=\text { 一定 }\right)
$$

（9）式は実験結果と一致する。すし前記（2）の過程が律速段階 であるとすれば，炭酸カルシウムの析出速度が $\mathrm{Ca}^{2+}$ 濃度に一次 であることが説明できない。以上の考察から炭酸かルシウムスケ 一ルの析出は結晶生成反応過程が律速であると考方られる。

（2）炭酸カルシウムの高温加水分解比よる水酸イオンの增加 に基つくく水酸化マグネシウムの析出について検討した結果，析出 速度は $\mathrm{Mg}^{2+}$ 濃に比例 L, $\mathrm{Ca}^{2+}$ 淟度に反比例すること, 溶存二 酸化炭素惯度は反湥過程中ほぼ一定であることが実験的に明らか となった。

水酸化マグネシウムスケールの析出過程は，（1）炭酸カルシ ウムの溶解過程，（2）炭酸イオンの加水分解による水酸イオン の生成過程，（3）水酸化マグネシウムの結晶析出過程，（4）生 成二酸化岸素の拡散脱離過程，の4段階からなると考えられる。 (3)の過程が律速段階であると仮定すればこの析出反応は次式で 表わされる。

$$
\begin{aligned}
& \mathrm{CaCO}_{3} \rightleftarrows \mathrm{Ca}^{2+}+\mathrm{CO}_{3}^{2-} \\
& \mathrm{CO}_{3}^{2-}+\mathrm{H}_{2} \mathrm{O} \rightleftarrows 2 \mathrm{OH}^{-}+\mathrm{CO}_{2} \\
& \mathrm{Mg}^{2+}+2 \mathrm{OH}^{-} \longrightarrow \mathrm{Mg}(\mathrm{OH})_{2} \text { (cryst.) }
\end{aligned}
$$

(10), (11) 式の平衡定数をそれぞれ $K_{4}, K_{5}$ とし，(12）式の速度 定数を $k_{2}{ }^{\prime}$, 水酸化マグネシウム析出速度を $r_{2}$ とおけば

$$
\begin{aligned}
& \left\{\begin{array}{l}
K_{4}=\left[\mathrm{Ca}^{2+}\right]\left[\mathrm{CO}_{3}^{2-}\right] \\
K_{5}=\left[\mathrm{OH}^{-}\right]^{2}\left[\mathrm{CO}_{2}\right] /\left[\mathrm{CO}_{3}{ }^{2-}\right] \\
r_{2}=k_{2}\left[\mathrm{Mg}^{2+}\right]\left[\mathrm{OH}^{-}\right]^{2}
\end{array}\right. \\
& \therefore \quad r_{2}=k_{2}\left[\mathrm{Mg}^{2+}\right] /\left[\mathrm{Ca}^{3+}\right]
\end{aligned}
$$

ここで

$$
k_{2}=K_{4} \cdot K_{5} \cdot k_{2}^{\prime} /\left[\mathrm{CO}_{2}\right]=\text { 一定 }\left(\because\left[\mathrm{CO}_{2}\right]=\text { 一定 }\right)
$$

（13）式は実験結果と一致する。すし前記（2）その他の過程が律 速段階であるとすれば，氷酸化マグネシウムの析出速度が $\mathrm{Mg}^{2+}$ 濃度に比例し $\mathrm{Ca}^{2+}$ 浀度に反比例することが説明でさない。以上 の考察から，水酸化マグネシウム析出も結晶反応過程が律速であ ることが帰納される。 


\title{
Deposition Mechanism of Alkaline Scale on the Heated Surface of the Boiler from the Aqueous Solution Containing Calcium and Magnesium Salts
}

\author{
Tadatoshi Goto and Takayasu ShIrasaki \\ Research Laboratory of Resources Utilization, Tokyo Institute of \\ Technology ; Ookayama, Meguro-ku, Tokyo, Japan
}

\begin{abstract}
We studied on the deposition mechanism of alkaline scale substances $\left(\mathrm{CaCO}_{3}, \mathrm{Mg}(\mathrm{OH})_{2}\right)$ on a heated surface. $\mathrm{CaCO}_{3}$ scale deposited on the heated surface by thermal decomposition of $\mathrm{HCO}_{8}-$. The deposition rate was represented by the equation, $r_{1}=k_{1}\left[\mathrm{Ca}^{2+}\right]\left[\mathrm{HCO}_{8}^{-}\right]^{2}$, and the apparent activation energy was $25 \mathrm{kcal} / \mathrm{mol}$. The dissolved $\mathrm{CO}_{2}$ concentration was constant through the process of this reaction. These observations imply that the formation of crystalline $\mathrm{CaCO}_{3}$ is the rate-determining step in this reaction.

$\mathrm{Mg}(\mathrm{OH})_{2}$ scale deposited on the heated surface by hydro-decomposition of $\mathrm{CaCO}_{3}$ scale in a $\mathrm{MgSO}_{4}$ solution. The deposition rate was represented by the equation, $r_{2}=k_{2}\left[\mathrm{Mg}^{2+}\right] /\left[\mathrm{Ca}^{2+}\right]$. The dissolved $\mathrm{CO}_{2}$ concentration was constant through the process of the reaction, too. These results suggest that the formation of crystalline $\mathrm{Mg}(\mathrm{OH})_{2}$ is the rate-determining step:

The experiment of the deposition of alkaline scale in sea water near the boiling temperature showed that $\mathrm{CaCO}_{8}$ scale deposited initially by thermal decomposition of $\mathrm{HCO}_{3}^{-}$, and successively $\mathrm{Mg}(\mathrm{OH})_{2}$ scale deposited by hydro-decomposition of $\mathrm{CaCO}_{2}$ scale. The other salts in sea water may not affect directly the deposition of $\mathrm{Mg}(\mathrm{OH})_{2}$ scale.
\end{abstract}

（日本化学会誌, 1972, p. 2313 2317)

\section{石炭を原料とする回分式流動賦活による球形活性炭の製造}

(1972 年9月 13 日受理)

\author{
渡辺 藤雄*・楖ヶ瀬 繁**. 杉山幸男*
}

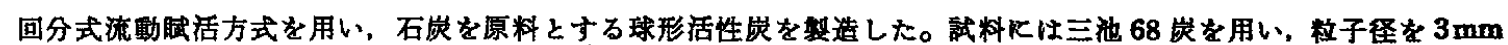

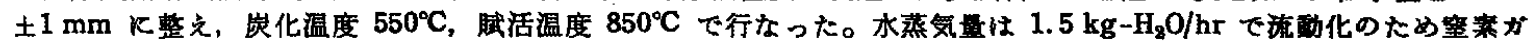
スを加え, 流動部の流速を $1.1 \mathrm{~m} / \mathrm{sec}$ Kした。得られた活性孷の吸着能の测定からベンぜン吸着においては実用上满 足できる結果が得られたが，メチレンブルー脱色力は従来のそれと比較して $1 / 2 \sim 1 / 3$ 程度であった。また，細孔分 有の測定からは全表面樌の micro-pore の占る割合がいすれる90\%以上飞達していることがわかり、このことから メチレンブルー脱色力の劣化現象をる考察した。流動倵活の有用性を檢討するため、流動化ガスを加えない固定床甈

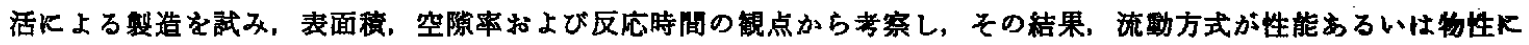

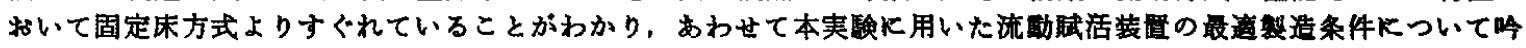
味した。

\section{1 楮言}

近年，環境污染に対する防止対策として，活性炭を使用する方 法が急速江注目されはじめた。環境污染の中には大気污染あるい は水質污摆などがあるが，これらの防止対策に合致するよらな活 性岸としては，機械的性質，構成的性筫めるいは吸着能，脱色能 なとの面炕括いて工業的に十分満足できるととるに，大量でしか る安価化代給されることが必要である。このよらな条件を满たす 原料の開発についてはすでに各方面でなされているが，とくに石 炭を原料とした球形活珄炭は流通抵抗の少ないことから産桠界か

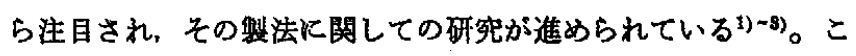

* 名古屋大学工学部化学工学数室, 名古屋市千種区不老町

** 日本硝子蟣維株式会社, 三重紧津市柳山建與平治町

1）本田英曷，日本化学工業，16，No.169，10(1968),
れらはおるに固定方式あるいはロータリーキルンによる筫造方法 の研究であり，流動方式による製造に関しては，その程済性につ いてはすでにいくつか報告されているが24)，樓成的性筫の面から の追求は十分なされてないよらに思われる。

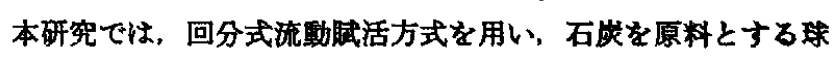
形活性炭の製造を試み，得られた試料について性費および性能の 測定を行ない，従来の固定休眗活によるそれと比較すると同時に それぞれの細孔分布，表面積分布に関して検討を加え，むわせて

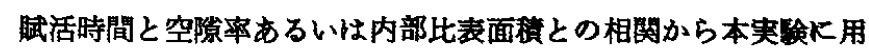

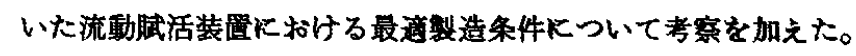

2) 本田英昌，科学と工業，42，405(1968).

3）北月浩, 結城仲治, 真田雄三, 渡 真治郎, 本田英甶、 工化, 72, 96(1969).

4）楖井 宏、化工壕，26，518(1962). 